\title{
Complementation Analysis of Fatty Acid Oxidation Disorders
}

\author{
Anne Moon and William J. Rhead \\ Department of Pediatrics, University of Iowa, Iowa City, Iowa 52242
}

\begin{abstract}
We assayed $\left[9,10(n)-{ }^{3} \mathrm{H}\right]$ palmitate oxidation by fibroblast monolayers from patients with fatty acid oxidation disorders. Activities in the different disorders were (percent control): short-chain acylcoenzyme A (CoA) dehydrogenase deficiency (115\%), medium chain acyl-CoA dehydrogenase deficiency (18\%), long-chain acyl-CoA dehydrogenase deficiency (28\%), multiple acyl-CoA dehydrogenation disorder, mild and severe variants (49\% and 7\%), and palmityl-carnitine transferase deficiency (4\%). Multiple acyl-CoA dehydrogenation disorder, medium chain acyl-CoA dehydrogenase-deficient lines, and long-chain acyl-CoA dehydrogenase-deficient lines all complemented one another after polyethylene glycol fusion, with average activity increases of 3183\%. We detected two complementation groups in the severe multiple acyl-CoA dehydrogenation disorder lines, consistent with deficiencies of either electron transfer flavoprotein or electron transfer flavoprotein:ubiquinone oxidoreductase. The metabolic block in the latter cell lines is threefold more severe than in the former $(P<0.001)$. No intragenic complementation was observed within either group. We assigned two patients with previously unreported severe multiple acyl-CoA dehydrogenation disorder to the electron transfer flavoprotein:ubiquinone oxidoreductase-deficient group.
\end{abstract}

\section{Introduction}

Fatty acid oxidation disorders include short-chain acyl-coenzyme A $(\mathrm{CoA})^{1}$ dehydrogenase deficiency (SCD), medium-chain acyl-CoA dehydrogenase deficiency (MCD), long-chain acylCoA dehydrogenase deficiency (LCD), the multiple acyl-CoA dehydrogenation disorders (MAD), and palmityl-carnitine transferase deficiency (PCT). SCD has been identified in infants

Related experiments appeared in an abstract (1986. Pediatr. Res. 20: 269a).

Address reprint requests to Dr. Rhead.

Received for publication 2 June 1986.

1. Abbreviations used in this paper: ADH, acyl-coenzyme A dehydrogenase; CoA, coenzyme A; ETF, electron transfer flavoprotein; ETF: $\mathrm{QO}$, electron transfer flavoprotein:coenzyme $\mathrm{Q}$ oxidoreductase; $\mathrm{LCD}$, long-chain acyl-coenzyme A dehydrogenase deficiency; MAD, multiple acyl-coenzyme A dehydrogenation disorder; MAD:M, multiple acylcoenzyme A dehydrogenation disorder, mild variant; MAD:S, multiple acyl-coenzyme A dehydrogenation disorder, severe variant; $M C D$, medium-chain acyl-coenzyme A dehydrogenase deficiency; MEM/10, Eagle's minimum essential medium with $10 \%$ fetal calf serum, $2 \mathrm{mM}$ glutamine, $140 \mu \mathrm{M}$ penicillin, $88 \mu \mathrm{M}$ streptomycin; PCT, palmityl-carnitine transferase deficiency; PEG, polyethylene glycol; SCD, short-chain acylcoenzyme A dehydrogenase deficiency.

J. Clin. Invest.

(c) The American Society for Clinical Investigation, Inc.

$0021-9738 / 87 / 01 / 0059 / 06 \$ 1.00$

Volume 79, January 1987, 59-64 excreting ethylmalonate and methylsuccinate $(1,2)$. MCD is characterized by episodic hypoketotic hypoglycemia and a medium-chain dicarboxylic aciduria, whereas LCD can also produce hypotonia and hypertrophic cardiomyopathy (3-5). The MAD are characterized biochemically by the inability of affected individuals to metabolize all the acyl-CoAs normally oxidized via the acyl-CoA dehydrogenases (6-9), whereas PCT-deficient patients have an isolated defect in long-chain fatty acid oxidation (10).

Clinical symptoms of the MAD include varied degrees of hypoketotic hypoglycemia, acidosis, fatty changes in liver, kidney, and sometimes heart, and accumulation and excretion of dethiolated acyl-CoAs and their derived oxidation products (8). Goodman and Frerman (8) have designated three clinical subgroups of MAD: neonatal onset MAD with congenital defects, neonatal onset MAD without congenital defects, and late onset MAD. The first two groups constitute the disorder's severe forms, MAD:S or glutaric aciduria type II. Fibroblasts from MAD:S patients oxidize radiolabeled fatty acids, leucine, and lysine very poorly (6-9). The late onset disorders, MAD:M, also termed ethylmalonic-adipic aciduria or mild glutaric aciduria type II, are milder forms of the disease in which the fibroblasts display less severe but analogous metabolic defects $(11,12)$.

We found previously that four MAD:S cell lines had electron transfer flavoprotein (ETF) activities $<6 \%$ of control, whereas two MAD:M lines had activities $29 \%$ and $38 \%$ of control (13). Frerman and Goodman recently assayed ETF:ubiquinone oxidoreductase (ETF:QO) activities in six MAD:S lines, demonstrating normal activity in two lines we found to be ETF deficient, and ETF:QO deficiency in the remaining four, three of which we study here (14).

Our complementation studies demonstrate the existence of two distinct complementation groups among MAD:S lines, as the previous studies would predict. We have also shown complementation between MCD, LCD, and MAD:M lines. The assay we have developed requires minimal quantities of cells and radiolabeled substrate, provides rapid, reliable results, and readily demonstrates enzymatic defects affecting palmitate oxidation in intact fibroblasts.

\section{Methods}

$\left[9,10(n)-{ }^{3} \mathrm{H}\right]$ palmitic acid was obtained from Research Products International Corp., Mt. Prospect, IL, and Amersham International, Amersham, Buckinghamshire, England. Final specific activity was $380 \mathrm{mCi}$ / $\mathrm{mmol}$; the substrate was stored at $-20^{\circ} \mathrm{C}$ in $n$-propanol. $50 \%$ polyethylene glycol (PEG) was obtained from Boehringer Mannheim Biochemicals (Indianapolis, IN). Fatty acid-free fraction $\mathrm{V}$ bovine serum albumin (BSA) and Dowex-1 anion exchange resin were from Sigma Chemical Co., St. Louis, MO. Skin fibroblasts were obtained from seven MAD:S patients who presented in the neonatal period, three females (1540, [8]; 1441, [15]; 1520 [16]) and four males (1400, [6]; 1430, [17]; 1515, [18]; 1401 , courtesy of Dr. Peggy Falace, University of Kentucky, Lexington, $\mathrm{KY}$ ). Patient 1401 is a male neonate who died at $3 \mathrm{~d}$ of age with severe metabolic acidosis, hypoglycemia, and a characteristic MAD:S organic aciduria. MAD:S lines A.C. and S.A. were obtained from Dr. C. Green- 
berg, Winnipeg, Manitoba, Canada, and Dr. B. Wilcken, Sydney, Australia, respectively. The MAD:M patients presented in infancy (493, [11]; 741, [19]; 840 and 930, courtesy of Dr. L. Sweetman, University of California, San Diego, CA). The SCD(N-II), MCD (S.G., A.M., R.B.), and $\operatorname{LCD}(\mathrm{R}-1)$ patients have been described previously $(1,2,5,20)$. Full clinical and biochemical descriptions of patients 1401, 840, 930, and N-II will be published separately. The PCT patient (S.V.) has been identified by Dr. R. Haas and Dr. W. Nyhan, University of California, San Diego, CA. Control fibroblast cultures were obtained from six normal individuals.

All cells were cultured in Eagle's minimal essential medium with nonessential amino acids supplemented with $10 \%$ fetal calf serum (FCS), $2 \mathrm{mM}$ glutamine, $140 \mu \mathrm{M}$ penicillin, and $88 \mu \mathrm{M}$ streptomycin (MEM/ 10). Fibroblasts were subcultured 1:4 bimonthly and the medium was changed weekly. Cells in passage 6-20 were used in all experiments. To prepare cells for the ${ }^{3} \mathrm{H}$-release assay, confluent monolayers were harvested with $0.25 \%$ trypsin, centrifuged for $3 \mathrm{~min}$ at $3,000 \mathrm{~g}$ and resuspended in MEM/10. The cell suspensions were counted and cells were plated in duplicate in two 24-well microtiter plates (Falcon Labware, Oxnard, CA) at a density of $10^{5}$ cells per line per $2-\mathrm{cm}^{2}$ well. Plates were then incubated for $24 \mathrm{~h}$ at $37^{\circ} \mathrm{C}$ in a $5 \% \mathrm{CO}_{2} / 95 \%$ air mixture.

In the plate to be fused, monolayers were rinsed three times with 1.5 ml Swims S-77 $\mathrm{Ca}^{+2}$-free media; the final rinse was left on the cells for $5 \mathrm{~min} .0 .1 \mathrm{ml} 50 \%$ PEG at $37^{\circ} \mathrm{C}$ was applied for $30 \mathrm{~s}$ immediately following aspiration of the final rinse; $1.5 \mathrm{ml}$ of Dulbecco's phosphatebuffered saline (PBS) was then added to the 50\% PEG solution and immediately aspirated from the monolayer. Five rapid $1.5-\mathrm{ml}$ washes with Swims S-77 followed. The plate containing the unfused monolayers was treated identically except for PEG application. Both plates were incubated at $37^{\circ} \mathrm{C}$ in $5 \% \mathrm{CO}_{2} / 95 \%$ air for $20 \mathrm{~h}$.

The reaction mixture was prepared by complete evaporation of propanol from the $\left[9,10(n)-\mathrm{H}^{3}\right]$ palmitic acid with a $5 \% \mathrm{CO}_{2} / 95 \%$ air stream. The $\left[{ }^{3} \mathrm{H}\right]$ palmitate was resuspended in Hanks' basic salt solution (HBSS) containing $10 \mathrm{mg} \mathrm{BSA} / \mathrm{ml}$ and brought to a final concentration of 22 $\mu \mathrm{M}\left[{ }^{3} \mathrm{H}\right]$ palmitate and $0.5 \mathrm{mg} / \mathrm{ml}$ BSA with HBSS. $0.2 \mathrm{ml}$ of this mixture was applied to wells containing unfused and fused monolayers rinsed twice with $1.5 \mathrm{ml}$ of Dulbecco's PBS. Blanks were prepared by applying $0.1 \mathrm{ml}$ methanol to both unfused and fused monolayers for $30 \mathrm{~s}$. Additional PEG-treated wells were also methanol killed and stained with Giemsa ( $1 / 10$ in Dulbecco's PBS) for 2 min to determine the proportion of fused cells. All monolayers were inspected before the application of reaction mixture, and only those monolayers with $>40 \%$ multinucleate cells in good condition were used.

Cells were incubated in the above reaction mixture for $2 \mathrm{~h}$ at $37^{\circ}$ in humidified $5 \% \mathrm{CO}_{2} / 95 \%$ air. After incubation, the reaction mixture was removed and added to a centrifuge tube containing $0.2 \mathrm{ml}$ of $10 \%$ (wt/ vol) trichloroacetic acid. Each well was rinsed with $0.1 \mathrm{ml}$ of Dulbecco's PBS, which was added to the tube. After $2 \mathrm{~min}$ at room temperature, the reaction mixture was centrifuged at $8,500 \mathrm{~g}$ in a Beckman microfuge for $5 \mathrm{~min}$. Supernatants were immediately removed, then $0.07 \mathrm{ml}$ of 6 $\mathrm{N} \mathrm{NaOH}$ was added and applied to a 1-ml Dowex-1 column in a pasteur pipette. Columns were rinsed with $1 \mathrm{ml}$ of distilled water, and the eluate was collected in a scintillation vial containing $10 \mathrm{ml}$ of Scintiverse I (Fisher Scientific Co., Pittsburg, PA). The samples were then counted.

The monolayer was rinsed twice in $1.5 \mathrm{ml}$ Dulbecco's PBS, sonicated

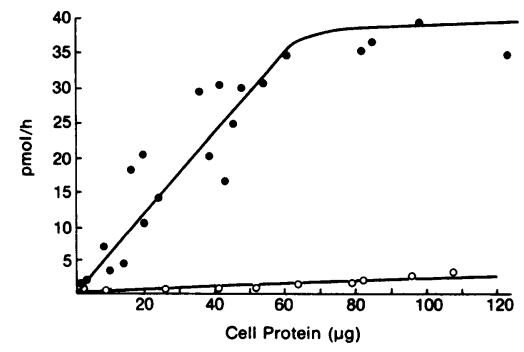

Figure 1. The dependence of ${ }^{3} \mathrm{H}$ release from $\left[9,10(n)-{ }^{3} \mathrm{H}\right]$ palmitate on cell protein for intact control (solid circle) and MAD:S (open circle) fibroblasts incubated for $2 \mathrm{~h}\left(37^{\circ} \mathrm{C}\right)$ in $22 \mu \mathrm{M}$ $\left.[9,10(n))^{3} \mathrm{H}\right]$ palmitate.

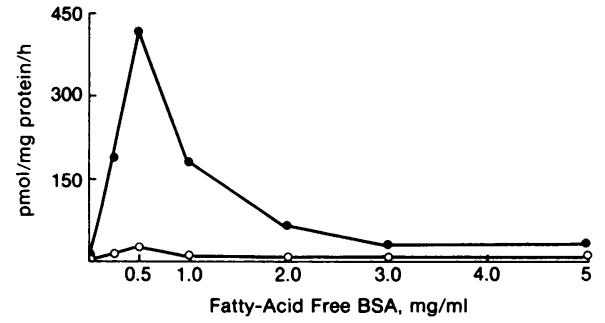

Figure 2. The dependence of ${ }^{3} \mathrm{H}$ release on BSA concentrations. Intact control (solid circle) and MAD:S (open circle) fibroblasts were incubated for $2 \mathrm{~h}\left(37^{\circ} \mathrm{C}\right)$ in $22 \mu \mathrm{M}\left[9,10(n)-{ }^{3} \mathrm{H}\right]$ palmitate in HBSS with varying concentrations of fatty acid-free BSA.

for $10 \mathrm{~s}$ in $0.2 \mathrm{ml}$ Dulbecco's PBS, and the protein content determined fluorometrically (21).

Activity is expressed as picomoles per milligram protein per hour. Variation is expressed as the standard error of the mean; unless stated otherwise, all $P$ values cited are two tailed and compare control cell lines with patient cell lines or fused with unfused combinations of cell lines.

\section{Results}

We optimized the parameters of the $\left[9,10(n)-{ }^{3} \mathrm{H}\right]$ palmitate oxidation assay to maximize control activity and resolution of fatty acid oxidation disorder phenotypes. Sensitivity of the assay is dependent on four major variables: substrate concentration, cell density, BSA concentration, and incubation time. Though the concentration of $\left[{ }^{3} \mathrm{H}\right]$ palmitate we employed routinely $(22 \mu \mathrm{M})$ is not fully saturating, $\leq 2 \%$ of the substrate is converted to ${ }^{3} \mathrm{H}_{2} \mathrm{O}$ by control cell lines (data available on request). The $\left[{ }^{3} \mathrm{H}\right]$ palmitate concentration is thus virtually constant throughout the incubation period, and MAD:S activities are consistently $<10 \%$ of control. The dependence of ${ }^{3} \mathrm{H}_{2} \mathrm{O}$ formation on cell density is displayed in Fig. $1 .{ }^{3} \mathrm{H}_{2} \mathrm{O}$ production was linear up to $\sim 60 \mu \mathrm{g}$ of cell protein per well, at which point the response levels off. All experiments reported here were performed with cell proteins ranging from 20 to $60 \mu \mathrm{g} /$ well. We assayed $\left[{ }^{3} \mathrm{H}\right]$ palmitate oxidation in a variety of media including MEM/ 10 and HBSS supplemented with FCS and/or varying concentrations of BSA. Optimal activity was observed in HBSS containing $0.5 \mathrm{mg} / \mathrm{ml}$ fatty acid-free BSA (Fig. 2; other data not shown). While activity increases linearly over $4 \mathrm{~h}$ of incubation (Fig. 3), we easily resolved patient from control cell lines in the more convenient period of $2 \mathrm{~h}$.

${ }^{3} \mathrm{H}_{2} \mathrm{O}$ production by the different cell lines is summarized in Table I. While the SCD cell line oxidized $\left[{ }^{3} \mathrm{H}\right]$ palmitate normally, activity in the MCD cell lines was $18 \%$ of control; activity in the LCD line was $28 \%$ of control $(P<0.05)$. The MAD:M cell lines catabolized the substrate more effectively at $31-63 \%$ of control and averaged $49 \%$ of control $(P<0.05)$. MAD:S activities ranged from 3 to $16 \%$ of control with a mean of $7 \%(P$ $<0.001)$. The PCT-deficient cell line had activity $4 \%$ of control $(P<0.001)$. The ${ }^{3} \mathrm{H}$-release assay thus readily detects intermediate and severe blocks in $\left[{ }^{3} \mathrm{H}\right]$ palmitate oxidation found in several fatty acid oxidation disorders. We then employed MCD, LCD, and MAD cell lines to define complementation groups with this system.

After PEG fusion, activities in all homokaryons were 95$100 \%$ of that in unfused cells. These changes were not statistically significant (Table I; $P>0.8$ ). As there were not activity differ- 


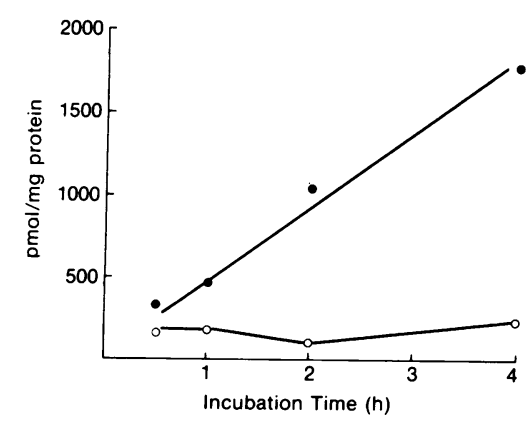

Figure 3. Time course of ${ }^{3} \mathrm{H}$-release from $\left[9,10(n)-{ }^{3} \mathrm{H}\right]$ palmitate by intact fibroblasts. Control (solid circle) and MAD:S (open circle) fibroblasts were incubated with $22 \mu \mathrm{M}[9,10(n)$ $\left.{ }^{3} \mathrm{H}\right]$ palmitic acid for varying times.

ences or complementation among the three MCD cell lines, we employed them interchangeably in these studies (data not shown). We then assayed unfused and fused combinations of control and patient cells (Table II). In all control/patient heterokaryons, activities after fusion were intermediate between those in control and patient cells, as expected, and were 74$106 \%$ of the prefusion values $(P>0.2)$. These mild activity decreases may result from the toxic effects of PEG on cell metabolism. Alternatively, since the acyl-CoA dehydrogenases and ETF are multimeric proteins, formation of mixed multimers between normal and mutant subunits may lower activities below prefusion values in control/patient heterokaryons. In contrast, MCD/LCD, MCD/MAD:M, LCD/MAD:M, MCD/MAD:S, and LCD/MAD:S heterokaryons demonstrated complementa-

Table I. ${ }^{3} \mathrm{H}_{2} \mathrm{O}$ Formation From $\left[9,10(n)-{ }^{3} \mathrm{H}\right]$ Palmitate and Effect of Polyethylene Glycol Fusion in Fibroblast Monolayers

\begin{tabular}{lccc}
\hline & \multicolumn{2}{l}{ Activity* } & \\
\cline { 2 - 3 } Cell lines & Unfused & Fused & $\begin{array}{c}\text { Percent change } \\
\text { with fusion }\end{array}$ \\
\hline & \multicolumn{2}{l}{ pmol/mg protein $/ h \pm S E M$} & \\
Normal control & $399 \pm 36$ & $383 \pm 59$ & -4 \\
SCD & & & \\
N-II & $459 \pm 97$ & - & - \\
MCD & & & \\
S.G. & $86 \pm 4^{\ddagger}$ & $82 \pm 3^{\ddagger}$ & -5 \\
A.M. & $61 \pm 11^{\ddagger}$ & $59 \pm 9^{\ddagger}$ & -3 \\
R.B. & $71 \pm 4^{\ddagger}$ & $68 \pm 4^{\ddagger}$ & -4 \\
LCD & & & \\
R-1 & $113 \pm 30^{\ddagger}$ & $113 \pm 12^{\ddagger}$ & 0 \\
MAD:M & & & \\
493 & $124 \pm 22^{\ddagger}$ & - & - \\
741 & $251 \pm 21$ & $250 \pm 9$ & 0 \\
840 & $223 \pm 9^{*}$ & $216 \pm 4$ & -3 \\
930 & $176 \pm 32^{\ddagger}$ & - & - \\
MAD:S & $29 \pm 4^{\S}$ & $28 \pm 4^{\S}$ & -4 \\
PCT deficiency & & & - \\
S.V. & $16 \pm 5^{\S}$ & - & - \\
\hline
\end{tabular}

For the unfused cultures, the number of determinations were 28 for the six control lines and 2 to 6 for patient cell lines. For the fused cultures, the number of determinations ranged from 2 to 8 for each cell line. No significant changes were noted with fusion $(P>0.4)$. Difference from normal control significant at $* P=0.05-0.1 ;{ }^{\ddagger} P<0.05 ;{ }^{8} P$ $<0.001$; " average value for the seven MAD:S lines used in this study; individual data are displayed in Table IV.
Table II. ${ }^{3} \mathrm{H}_{2} \mathrm{O}$ Formation in Coplated Control/Patient Cells

\begin{tabular}{lccc}
\hline $\begin{array}{l}\text { Patient cell lines } \\
\text { coplated with } \\
\text { normal controls* }\end{array}$ & Activity* & & $\begin{array}{l}\text { Percent change } \\
\text { with fusion }\end{array}$ \\
\cline { 2 - 3 } & Unfused & Fused & -26 \\
MCD & $155 \pm 4$ & $123 \pm 9$ & \\
MAD:S & & & -10 \\
1540 & $79 \pm 8$ & $71 \pm 15$ & -13 \\
1515 & $65 \pm 6$ & $56 \pm 12$ & -26 \\
1520 & $111 \pm 17$ & $82 \pm 94$ & +4 \\
1400 & $191 \pm 31$ & $200 \pm 12$ & +6 \\
1441 & $135 \pm 31$ & $143 \pm 14$ & -17 \\
1401 & $138 \pm 14$ & $115 \pm 11$ & -11 \\
1430 & $110 \pm 12$ & $98 \pm 14$ &
\end{tabular}

* All patient cell lines were coplated with 2-4 different control lines. No significant changes were noted with fusion $(P>0.2)$.

${ }^{\ddagger}$ picomoles product per milligram protein per hour \pm SEM; the number of determinations ranged from two to six.

tion with activity increases ranging from 31 to $83 \%$ relative to unfused cell mixtures (Table III; one tail $P=0.01-0.04$ ).

Complementation analyses between the MAD:S lines are presented in Table IV. All MAD:S homokaryons failed to complement; activities of noncomplementing heterokaryons decreased an average of $15 \%$ relative to unfused cell mixtures ( $P$ $>0.2$ ). Activity increases in complementing MAD:S heterokaryons ranged from 67 to $830 \%$ and averaged $207 \%(P<0.001)$. One-tail $P$ values for individual complementing crosses were $<0.03$, with a single exception $(1520 \times 1400)$, in which the increase was $130 \%$ (one tail $P=0.07$ ). On the basis of these data, the MAD:S lines can be assigned to two distinct complementation groups, as predicted by the enzymatic studies discussed previously. ETF-deficient lines previously described are 1400,1430 , and $1441(6,13,15,17)$. Our results allow us to assign an additional line, 1401, to this complementation group. ETF:QO-deficient lines identified by these and earlier studies are $1540(8), 1520(16)$, and $1515(18)$. We have recently studied two other cell lines (S.A. and A.C.) from patients with a clinical

Table III. Complementation in MCD/LCD, $M C D / M A D$, and $L C D / M A D$ Combinations

\begin{tabular}{|c|c|c|c|c|}
\hline \multirow{2}{*}{$\begin{array}{l}\text { Cell line } \\
\text { (number of lines) }\end{array}$} & \multirow{2}{*}{$\begin{array}{l}\text { Cell line } \\
\text { (number of lines) }\end{array}$} & \multicolumn{2}{|l|}{ Activity* } & \multirow[b]{2}{*}{$\begin{array}{l}\text { Percent change } \\
\text { with fusion }\end{array}$} \\
\hline & & Unfused & Fused & \\
\hline $\operatorname{MCD}(2)$ & LCD (1) & $92 \pm 10$ & $168 \pm 23$ & $+83^{\S}$ \\
\hline MCD (2) & MAD:M $(3)^{\ddagger}$ & $77 \pm 9$ & $133 \pm 19$ & $+73^{\S}$ \\
\hline LCD (1) & MAD:M (4) & $105 \pm 6$ & $137 \pm 14$ & $+31^{11}$ \\
\hline MCD (3) & MAD:S (7) & $42 \pm 3$ & $73 \pm 8$ & $+74^{8}$ \\
\hline $\mathrm{LCD}(1)$ & MAD:S (2) & $81 \pm 7$ & $109 \pm 4$ & $+34^{\prime \prime}$ \\
\hline
\end{tabular}

* picomoles product per milligram protein/hour \pm SEM; the number of determinations ranged from 1 to 13 for individual combinations of cell lines.

${ }^{\ddagger}$ Line 930 was not included in these experiments.

${ }^{8}$ Change with fusion significant at $P<0.05$.

"Change with fusion significant at $P=0.05-0.1$. 
Table IV. Complementation in MAD:S/MAD:S Combinations

\begin{tabular}{lcccccc}
\hline Cell line & 1540 & 1515 & 1520 & 1400 & 1441 & 1401 \\
\hline 1540 & $9 \pm 2 / 13 \pm 1^{*}$ & & & & & \\
1515 & $5 \pm 2 / 8 \pm 2$ & $14 \pm 3 / 13 \pm 2$ & & & & \\
1520 & $18 \pm 2 / 32 \pm 3$ & $11 \pm 2 / 16 \pm 2$ & $20 \pm 5 / 14 \pm 1$ & & & \\
1400 & $54 \pm 1^{\ddagger} / 33 \pm 4$ & $128 \pm 2^{8} / 35 \pm 6$ & $138 \pm 42 / 60 \pm 8$ & $59 \pm 8 / 69 \pm 7$ & & \\
1441 & $66 \pm 3^{8} / 22 \pm 2$ & $57 \pm 7^{8} / 16 \pm 3$ & $113 \pm 32^{8} / 32 \pm 3$ & $52 \pm 8 / 47 \pm 15$ & $26 \pm 4 / 42 \pm 8$ & $20 \pm 31 / 20 \pm 4$ \\
1401 & $50 \pm 4^{8} / 13 \pm 1$ & $41 \pm 12^{8} / 4 \pm 1$ & $90 \pm 7^{8} / 15 \pm 1$ & $22 \pm 4 / 39 \pm 1$ & $16 \pm 2 / 18 \pm 3$ & $18 \pm 4 / 17 \pm 4$ \\
1430 & $47 \pm 2^{8} / 16 \pm 1$ & $37 \pm 4^{8} / 11 \pm 11$ & $53 \pm 8^{8} / 27 \pm 3$ & $36 \pm 5 / 38 \pm 4$ & $28 \pm 4 / 49 \pm 8$ & $28 \pm 8 / 32 \pm 17$ \\
& & & & & & \\
\hline
\end{tabular}

* Activity expressed in picomoles product per milligram protein per hour \pm SEM. Activities in fused cells are displayed to the left of those of unfused cells (i.e., fused/unfused); the number of determinations ranged from three to seven for each combination. ${ }^{\ddagger}$ Change with fusion significant at $P=0.05-0.1$. ${ }^{8}$ Change with fusion significant at $P<0.05$.

diagnosis of MAD:S (Table V). Activities did not increase in homokaryons of both cell lines (data not shown). Both cell lines complemented MCD and ETF-deficient MAD:S cell lines in our assay system, with activity increases of 63-140\% (one tail $P$ $<0.05$ ), and did not complement ETF:QO-deficient lines. Thus, we assign the diagnosis of MAD:S due to ETF:QO deficiency to these two patients.

\section{Discussion}

The fatty acid oxidation disorders are a group of diseases involving defects in $\beta$-oxidation and acyl-CoA metabolism. Assays for detection and characterization of the biochemical defects in these disorders are essential tools for clinical diagnosis and research. We have developed a sensitive, reliable, and rapid assay for disorders affecting $\beta$-oxidation of long-chain fatty acids, i.e., palmitate. Other intact cell screening assays for these disorders

Table V. Complementation Analysis of Two New MAD:S Cell Lines

\begin{tabular}{|c|c|c|c|c|}
\hline \multirow{2}{*}{$\begin{array}{l}\text { Patient } \\
\text { cell line }\end{array}$} & \multirow[b]{2}{*}{ Known cell line } & \multicolumn{2}{|l|}{ Activity* } & \multirow{2}{*}{$\begin{array}{l}\text { Percent } \\
\text { change } \\
\text { with fusion }\end{array}$} \\
\hline & & Unfused & Fused & \\
\hline S.A. & MCD & $37 \pm 6$ & $60 \pm 10$ & $+63^{\prime \prime}$ \\
\hline S.A. & ETF deficient MAD:S ${ }^{\ddagger}$ & $21 \pm 7$ & $44 \pm 9$ & $+114^{\prime \prime}$ \\
\hline S.A. & $\begin{array}{l}\text { ETF:QO deficient } \\
\text { MAD:S }\end{array}$ & $12 \pm 6$ & $8 \pm 2$ & -31 \\
\hline A.C. & MCD & $63 \pm 6$ & $127 \pm 15$ & $+101^{1}$ \\
\hline A.C. & ETF deficient MAD:S ${ }^{\ddagger}$ & $28 \pm 1$ & $68 \pm 5$ & $+140^{\prime}$ \\
\hline A.C. & $\begin{array}{l}\text { ETF:QO deficient } \\
\text { MAD:S } \text { S }^{\S}\end{array}$ & $20 \pm 4$ & $13 \pm 4$ & -36 \\
\hline
\end{tabular}

* picomoles product per milligram protein per hour $\pm \mathrm{SEM}$; the number of determinations were 3-6 for each cell combination.

${ }^{\ddagger}$ Lines 1400,1401 , and 1441 .

${ }^{8}$ Lines 1515 and 1540 .

"Change with fusion significant at $P=0.05-0.1$.

' Change with fusion significant at $P<0.05$. include quantitating conversion of ${ }^{14} \mathrm{C}$ from ${ }^{14} \mathrm{C}$-fatty acids to ${ }^{14} \mathrm{CO}_{2}$ or ${ }^{14} \mathrm{C}$-labeled cellular protein $(3-12,22)$. In disrupted or fractionated cells, direct enzyme assays can detect deficiencies of the acyl-CoA dehydrogenases, ETF, ETF:QO, and PCT (3$5,13,14,23)$. Immunoblotting and immunoprecipitation techniques have demonstrated molecular heterogeneity of the acylCoA dehydrogenases (ADH), ETF, and ETF:QO in these disorders $(14,24,25)$.

The ${ }^{3} \mathrm{H}$ release/complementation system we describe here has certain advantages. It requires relatively small quantities of cells (20-60 $\mu$ g cell protein) and radiolabeled substrate $(1.5 \mu \mathrm{Ci})$ per determination. The importance of BSA in our system is clear from Fig. 2. Activity of control and MAD:S cells increases linearly with BSA concentrations up to $0.5 \mathrm{mg} / \mathrm{ml}$, after which point activity rapidly declines. With greater BSA concentrations, we hypothesize that a much larger proportion of total palmitate remains bound to extracellular BSA and the intracellular substrate concentration does not permit maximal substrate oxidation. The plateau in activity seen at cell proteins above $60 \mu \mathrm{g} /$ well suggests that confluent fibroblast monolayers may have lower energy needs than actively dividing cells (other data not shown). As the assay is very rapid, results can be obtained $3 \mathrm{~h}$ after substrate application. Because the assay is performed in microtiter dishes, manipulations are quick and unencumbered. We have fused twelve cell lines and assayed 120 wells in a single experiment. Experiments of this scale are unwieldy in other systems. The relative simplicity of the fusion and assay procedures permits numerous repetitions of all fusions, so that complementation assignments are statistically sound. Finally, the sensitivity of this assay equals or surpasses all other methods previously employed in our laboratory (22).

This assay can detect a wide variety of disorders and distinguish them from one another by both absolute levels of residual activity and complementation: PCT cells cannot transport palmityl moieties as palmityl-carnitine into mitochondria and therefore show severely defective palmitate oxidation (10). MAD:S cells are severely deficient in their ability to oxidize $\left[{ }^{3} \mathrm{H}\right]$ palmitate because acyl-CoA dehydrogenation is blocked at ETF or ETF:QO. These flavoproteins sequentially transfer reducing equivalents from the three straight-chain ADHs and isovaleryl-CoA, glutaryl-CoA, 2-methyl branched-chain acyl-CoA, sarcosine, and dimethylglycine dehydrogenases to coenzyme $Q$ 
(7-9). When ETF and ETF:QO are functionally defective, all of these dehydrogenases are secondarily inhibited. For the tritium of $\left[9,10(n)-{ }^{3} \mathrm{H}\right]$ palmitate to be released as ${ }^{3} \mathrm{H}_{2} \mathrm{O}$, sequential dehydrogenation by both long-chain and medium-chain acyl-CoA dehydrogenase (LCADH, MCADH) are necessary. But LCADH and MCADH function poorly in the MAD because electron transfer to coenzyme $Q$ is impaired. LCD cells have decreased activity because ${ }^{3} \mathrm{H}$ will not be removed by MCADH until LCADH has initiated several cycles of $\beta$-oxidation. Hale et al. found that LCD line $\mathrm{R}-1$ oxidized $\left[16-{ }^{14} \mathrm{C}\right]-$ and $\left[{ }^{14} \mathrm{C}(\mathrm{U})\right]$ palmitate at $12 \%$ and $20 \%$ of control rates, respectively, roughly comparable to the $28 \%$ of control we find in the same line (5). After four cycles of $\beta$-oxidation, $\left[9,10(n)-{ }^{3} \mathrm{H}\right]$ palmitate is converted to $\left[1,2(n)-{ }^{3} \mathrm{H}\right]$ octanyl-CoA. It is not surprising that $\left[9,10(n)-{ }^{3} \mathrm{H}\right]$ palmitate and $\left[1-{ }^{14} \mathrm{C}\right]$ octanoate oxidation are similarly impaired in MCD cell lines (18-22\% of control; 3,4$)$. This system should also detect riboflavin-responsive defects in $\beta$-oxidation after culture of cells in riboflavin-free media (26), although we have not yet studied cell lines from such patients. Theoretically, this method should resolve any disorder where $\beta$ oxidation of long- and/or medium-chain fatty acids is impaired. In summary, this assay provides a powerful tool for screening cell lines for errors in fatty acid metabolism and determines the existence and severity of a block in the pathway. Fusion and complementation analysis against a selected panel of known mutant cell lines then assigns the specific enzymatic defect.

Among the MAD:S cell lines tested, we find two complementation groups corresponding to defects in ETF and ETF: QO. Our assignments concur with all previous reports $(13,14$, 25). We have confirmed our assignment of ETF deficiency to MAD:S line 1401 by direct enzyme assay (13). As those ETFdeficient immunochemically studied MAD:S lines (1400, 1430, 1441) have had abnormal $\alpha$-ETF subunits (25), our results suggest that cell line 1401 also has an $\alpha$-ETF abnormality. Our assay system should also detect another MAD:S complementation group corresponding to defects in the $\beta$-subunit of ETF, although no such cases have yet been identified. We found no intragenic complementation within the ETF- and ETF:QO-deficient MAD:S groups. While MAD:M lines also complement MCD and LCD cell lines, we have not yet assigned new MAD: $M$ lines to the ETF- or ETF:QO-deficient groups. This approach should prove quite feasible. We also find the metabolic block in the ETF:QO-deficient MAD:S lines is threefold more severe than in ETF-deficient lines $(P<0.001)$. Since MAD:S patients with ETF:QO deficiency have distinctive congenital malformations, whereas those with ETF deficiency do not $(8,13,14)$, the severity of the metabolic block, rather than its location, and the resulting profound acidosis in utero may have disturbed normal morphogenesis.

\section{Acknowledgments}

We thank Drs. F. Frerman, S. Goodman, N. Gregersen, C. Greenberg, R. Haas, S. Kahler, W. Nyhan, H. Przyrembel, J.-M. Saudubray, B. Steinman, L. Sweetman, K. Tanaka, F. Walther, U. Wendel, and B. Wilcken for cell lines and biochemical and clinical information from their patients, Ms. Lisa Teel for technical assistance, and Ms. B. McKean for preparation of the manuscript.

This work was supported by U. S. Public Health Service grants HD00380 and AM-33289, and National Foundation March of Dimes grants 5-297 and 1-876.

\section{References}

1. Amendt, B., B. Norbeck, A. Moon, and W. Rhead. 1984. $\beta$-Oxidation defects in man: short-, medium- and long-chain acyl-CoA dehydrogenase (ADH) deficiencies. Am. J. Hum. Genet. 36:55a. (Abstr.)

2. Amendt, B., B. Norbeck, A. Moon, and W. Rhead. 1985. A new defect of $\beta$-oxidation: short chain acyl-CoA dehydrogenase (SCADH) deficiency. Pediatr. Res. 19:309a. (Abstr.)

3. Rhead, W., B. Amendt, K. Fritchman, and S. Felts. 1983. Dicarboxylic aciduria: deficient $\left[1-{ }^{14} \mathrm{C}\right]$ octanoate oxidation and medium chain acyl-CoA dehydrogenase activity in fibroblasts. Science (Wash. DC). 221: 73-75.

4. Coates, P., D. Hale, C. Stanley, B. Corkey, and J. Cortner. 1985. Genetic deficiency of medium-chain acyl coenzyme A dehydrogenase: studies in cultured skin fibroblasts and peripheral mononuclear leukocytes. Pediatr. Res. 19:671-676.

5. Hale, D., M. Batshaw, P. Coates, F. Frerman, S. Goodman, I. Singh, and C. Stanley. 1985. Long-chain acyl coenzyme A dehydrogenase deficiency: an inherited cause of nonketotic hypoglycemia. Pediatr. Res. 19:665-671.

6. Pryzrembel, H., U. Wendel, K. Becker, H. J. Bremer, L. Bruinvis, D. Ketting, and S. K. Wadman. 1976. Glutaric aciduria type II: report on a previously undescribed metabolic disorder. Clin. Chim. Acta. 66: 227-239.

7. Gregerson, N. 1985. Acyl-CoA dehydrogenation disorders. Scand. J. Clin. Invest. 45(Suppl. 174):1-60.

8. Goodman, S. E., and F. E. Frerman. 1984. Glutaric acidaemia type II (multiple acyl-CoA dehydrogenation deficiency). J. Inherited Metab. Dis. 7(Suppl. 1):33-37.

9. Tanaka, K., and L. Rosenberg. 1983. Disorders of branched chain amino acid and organic acid metabolism. In The Metabolic Basis of Inherited Disease. J. B. Stanbury, J. B. Wyngaarden, D. S. Fredrickson, J. L. Goldstein, and M. S. Brown, editors. McGraw-Hill, New York. Fifth ed. 440-473.

10. Saudubray, J. M., F. X. Coude, F. Demaugre, C. Johnson, K. Gibson, and W. Nyhan. 1982. Oxidation of fatty acid in cultured fibroblasts: a model system for the detection and study of defects in $\beta$-oxidation. Pediatr. Res. 16:877-881.

11. Mantagos, S., M. Genel, and K. Tanaka. 1979. Ethylmalonicadipic aciduria. J. Clin. Invest. 64:1580-1589.

12. Dusheiko, G., M. C. Kew, B. I. Joffe, J. R. Lewin, S. Mantagos, and K. Tanaka. 1979. Glutaric aciduria type II: a cause of recurrent hypoglycemia in an adult. $N$. Engl. J. Med. 301:1405-1409.

13. Amendt, B., and W. Rhead. 1986. The multiple acyl-CoA dehydrogenation disorders, glutaric aciduria type II and ethylmalonic-adipic aciduria: mitochondrial fatty acid oxidation, acyl-CoA dehydrogenase and electron-transfer flavoprotein activities in fibroblasts. J. Clin. Invest. 78:205-213.

14. Frerman, F., and S. Goodman. 1985. Deficiency of electron transfer flavoprotein or electron transfer flavoprotein: ubiquinone oxidoreductase in glutaric acidemia type II fibroblasts. Proc. Natl: Acad. Sci. USA. 82:4517-4520.

15. Goodman, S. I., D. O. Stene, E. R. B. McCabe, M. D. Norenberg, R. H. Shikes, D. A. Stumpf, and G. K. Blackburn. 1982. Glutaric aciduria type II: clinical, biochemical and morphologic considerations. J. Pediatr. 100:946-950.

16. Gregersen, N., S. Kolvraa, K. Rasmussen, E. Christensen, N. J. Brandt, F. Ebbesen, and F. H. Hansen. 1980. Biochemical studies in a patient with defects in the metabolism of acyl-CoA and sarcosine: another possible case of glutaric aciduria type II. J. Inherited Metab. Dis. 3:6772.

17. Niederwiser, A., B. Steinmann, U. Exner, F. Neuheiser, U. Redwiek, M. Wang, S. Rampini, and U. Wendel. 1983. Multiple acyl-CoA dehydrogenation deficiency (MADD) in a boy with nonketotic hypoglycemia, hepatomegaly, muscle hypotonia and cardiomyopathy. Detection of $\mathrm{N}$-isovalerylglutamic acid and its monoamide. Helv. Paediatr. Acta. 38:9-26. 
18. Coude, F. X., H. Ogier, C. Charpentier, G. Thomassin, A. Checoury, O. Amedee-Manesme, J. M. Saudubray, and J. Frezal. 1980 Neonatal glutaric aciduria type II: an X-linked recessive inherited disorder. Hum. Genet. 59:263-265.

19. Duran, M., F. Walter, L. Bruinvis, and S. Wadman. 1983. The urinary excretion of ethylmalonic acid. What level requires further attention? Biochem. Med. 29:171-175.

20. Amendt, B., and W. Rhead. 1985. Catalytic defect of mediumchain acyl-coenzyme A dehydrogenase deficiency. Lack of both cofactor responsiveness and biochemical heterogeneity in eight patients. J. Clin. Invest. 76:963-969.

21. Bohlen, P., S. Stein, W. Dairman, and S. Udenfriend. 1973. Fluorometric assay of proteins in the nanogram range. Arch. Biochem. Biophys. 155:213-220.

22. Rhead, W., K. Henkle, A. Moon, and V. Roettger. $1985 .{ }^{14} \mathrm{C}-$ labelled substrate catabolism by human diploid fibriblasts derived from infants and adults. Biochem. Med. 34:182-188.

23. Bougneres, P., J. M. Saudubray, C. Marsac, M. Coiever, and J. Girard. 1981. Fasting hypoglycemia resulting from hepatic carnitine palmityl transferase deficiency. J. Pediatr. 98:742-747.

24. Ikeda, Y., S. Keese, P. Coates, and K. Tanaka. 1985. Molecular study of mutant medium chain acyl-CoA dehydrogenase from patients with medium chain acyl-CoA dehydrogenase deficiency. Pediatr. Res. 19;249a. (Abstr.)

25. Ikeda, T., S. Keese, and K. Tanaka. 1985. Molecular heterogeneity of electron transfer flavoprotein (ETF) in glutaric acidemia type II due to an ETF deficiency. Pediatr. Res. 19:249a. (Abstr.)

26. Rhead, W., and K. Fritchman. 1983. Riboflavin-responsive ethylmalonic-adipic aciduria (RR-EMA): in vitro confirmation of vitamin responsiveness in intact fibroblasts. Pediatr. Res. 17:218a. (Abstr.) 